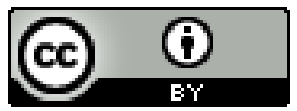

\title{
AS RUAS FALAM: COTIDIANO, OFÍCIOS E ESPAÇO URBANO NO RIO DE JANEIRO OITOCENTISTA (1810-1860)
}

\author{
Antonio Ramos Bispo Netol
}

\begin{abstract}
Resumo: Este artigo visa analisar, através do exame do cotidiano do espaço urbano da cidade do Rio de Janeiro, a presença de oficiais ligados a construção, produção e reparo dos mais diversos itens essenciais para a sociedade de então. A partir da caracterização, e da discussão de aspectos da vida cotidiana de carpinteiros, marceneiros, canteiros, ferreiros, serralheiros, dentre outros, buscaremos trazer para o centro da discussão aspectos ligados ao acesso ao letramento, instrução, aquisição de uma cultura monetária, doenças e mazelas, daqueles que erigiram as cidades e as riquezas da sociedade oitocentista.
\end{abstract}

Palavras-chave: cotidiano; artesãos; africanos

\section{THE STREETS SPEAK: EVERYDAY LIFE, CRAFTS AND URBAN SPACE IN 19th CENTURY RIO DE JANEIRO (1810-1860)}

\begin{abstract}
This article aims to analyze, through the examination of the everyday life of the urban space in the city of Rio de Janeiro, the presence of craftsmen who worked in the construction, production and repair of the most diverse essential items to society at that time. Based on the characterization, and the discussion of aspects of the daily life of carpenters, joiners, stoneworkers, blacksmiths, locksmiths, among others, we will seek to bring to the center of the discussion aspects related to access to literacy, instruction, acquisition of a monetary culture, diseases and ills, of those who built the cities and the wealth of 19th century society.
\end{abstract}

Keywords: everyday life; craftsmen; africans

\section{LAS CALLES HABLAN: VIDA COTIDIANA, OFICIOS Y ESPACIO URBANO EN EL SIGLO XIX EN RIO DE JANEIRO (1810-1860)}

Resumen: Este artículo tiene como objetivo analizar, a través del examen de la vida cotidiana del espacio urbano en la ciudad de Río de Janeiro, la presencia de artesanos

\footnotetext{
${ }^{1}$ Bacharel e Licenciando em História pela Universidade Federal do Rio Janeiro (UFRJ), mestre em História Comparada (PPGHC) pela mesma universidade. E-mail: antonio_rbn@ hotmail.com
}

Revista da ABPN • v. 12, n. Ed. Especial - Caderno Temático: "Africanos, escravizados, libertos biografias, imagens e experiências atlânticas" • agosto de 2020, p. 140-171 
vinculados a la construcción, producción y reparación de los más diversos elementos esenciales para la sociedad en ese momento. Con base en la caracterización y la discusión de aspectos de la vida cotidiana de carpinteros, ebanistas, silleros, herreros, cerrajeros, entre otros, buscaremos llevar al centro de la discusión aspectos relacionados con el acceso a la alfabetización, instrucción, adquisición de una cultura monetaria, enfermedades y males, de aquellos que construyeron las ciudades y la riqueza de la sociedad del siglo XIX.

Palabras-clave: cotidiano; artesanos; africanos

\section{LES RUES PARLENT: VIE QUOTIDIENNE, ARTISANAT ET ESPACE URBAIN DANS LE RIO DE JANEIRO DU 19ème SIÈCLE (1810-1860)}

Resumé: Cet article vise à analyser, par l'examen de la vie quotidienne de l'espace urbain de la ville de Rio de Janeiro, la présence d'artisans liés à la construction, la production et la réparation des éléments les plus divers essentiels à la société de l'époque. À partir de la caractérisation et de la discussion des aspects de la vie quotidienne des charpentiers, menuisiers, tailleures de pierre, forgerons, serruriers, entre autres, nous chercherons à mettre au centre de la discussion les aspects liés à l'accès à l'alphabétisation, à l'instruction, à l'acquisition d'une culture monétaire, aux maladies et les blessures, de ceux qui ont construit les villes et la richesse de la société du XIXe siècle.

Mots-clés: quotidienne; artisans; africans

\section{INTRODUÇÃO}

Consideramos que a vida cotidiana nos oferece perspectivas interessantes acerca de qualquer sociedade, revelando a repetição de costumes, gestos, e outras práticas diárias, e as relações sociais, espacialidades, temporalidades intrínsecas às mesmas. As cidades, palcos privilegiados da análise da vida cotidiana pretérita, são também portadoras de diversas temporalidades possíveis de serem vistas pelas construções ainda preservadas, monumentos, praças, largos, ruas, becos e pelas suas transformações ao longo do tempo, isto é: as intervenções estatais e privadas no solo urbano, configurando-se no desaparecimento de quarteirões, bairros, comunidades etc para a abertura de vias rodoviárias, metroviárias e ferroviárias, ou outras construções, que alteram a forma, conteúdo e valor dos espaços urbanos.

Ainda assim, o que se preserva, e o que é possível de ser analisado através de pesquisas arqueológicas e históricas desvelam espaços, paisagens, territórios, ritmos temporais, desse passado, marcado no espaço - este, entendido como uma sobreposição

Revista da ABPN • v. 12, n. Ed. Especial - Caderno Temático: "Africanos, escravizados, libertos biografias, imagens e experiências atlânticas” • agosto de 2020, 
de tempos e experiências (SANTOS, 2006, pp. 66-71; TUAN, Yi-Fu, 1975, pp. 151-165 apud LEMOS, 2011, p. 76). Por isso, aqui, nos perguntamos acerca de quem construiu essa paisagem? Quais as origens dessas pessoas e em que período viveram? E o que eles podem nos dizer acerca da própria cidade, que memórias foram esquecidas e/ou apagadas? Através da análise do cotidiano dos praticantes ordinários do espaço, como afirmou Certeau (1996, pp. 38-51) - no qual, os mesmos, apropriam-se dos espaços urbanisticamente definidos, dando-lhes sentidos -, numa cidade escravista, como era o Rio de Janeiro no oitocentos, onde a vigilância privada e do Estado - como uma novidade - em relação aos cativos era uma frequente, a análise do cotidiano apresenta os diversos "procedimentos" e "táticas" utilizadas por essas pessoas, no qual demarca-se a própria produção do espaço urbano. Procedimentos e táticas cotidianas que demonstram a assimilação de certas relações sociais. (HELLER, 2008)

Nas relações sociais em que ser liberto significava condições mais autônomas de existência - assentar praça, casar, ter propriedade, moradia -, a manipulação de certos gestos, costumes, modos de vestir-se e falar, apreendidas a partir da análise do cotidiano daquela cidade - e seus arredores,-mostram a assimilação dessas relações sociais por parte dos escravizados. Como é no espaço, doméstico ou da rua, que se dá o cotidiano, numa relação em que as pessoas agem sobre um espaço já construído, mas que transforma-se a partir da ação das mesmas, podemos perscrutar experiências e espacialidades de um cotidiano marcado pela manipulação de condutas, costumes e gestos já assimilados.

Buscamos, portanto, apresentar alguns resultados de pesquisa recente, objetivando, aqui, problematizar certos pontos em torno da importância da população africana e afrodiaspórica na construção das riquezas do Brasil, no oitocentos e séculos anteriores; e na importância dessas mesmas experiências para o entendimento das questões relativas aos mundos do trabalho, já formalmente livre. Assim, analisaremos esse quadro, neste artigo, sob alguns aspectos: em primeiro lugar, a demografia desses oficiais na cidade e também seus arredores -, a partir de estudos historiográficos sobre a demografia na Corte e um levantamento demográfico a partir de periódicos como o Gazeta do Rio de Janeiro, Diário do Rio de Janeiro, Jornal do Commercio e Correio Mercantil etc. Os caracterizados como africanos, crioulos, pardos etc. tinham certa proeminência nessa ou

Revista da ABPN • v. 12, n. Ed. Especial - Caderno Temático: "Africanos, escravizados, libertos biografias, imagens e experiências atlânticas” • agosto de 2020, 
naquela especialidade? Dentre os africanos, havia diferenças entre as "nações" e os ofícios?

Em um segundo momento, partimos das fugas, e que as mesmas não representam somente uma manifestação de revolta contra a escravidão, mas estavam inseridas, muitas vezes, em suas intenções, aos próprios quadros da lógica e cotidiano escravista em que tais agentes estavam postos. Ou seja, muitas vezes, como veremos, cativos eram “fujões" reincidentes, e as fugas eram, como sabemos, algo esperado pelos senhores, mas mobilizavam os interesses dos próprios cativos. Numa terceira parte, analisaremos as condições de salubridade que estavam inseridos os oficiais metalúrgicos na cidade. Postos sob condições precárias de trabalho, esses artistas e operários contavam com marcas de mazelas e castigos que funcionavam como um diferenciador dos mesmos, nos anúncios, frente a outros cativos e libertos. "Sinais diacríticos" ou "narrativas do corpo" (GOMES \& SOARES, 2001, pp. 15-16; VIANA \& GOMES, 2019, p. 93) que podiam relacionar marcas corporais a certos ofícios, e demarcar possíveis diferenças entre grupos, que indicam condições de trabalho, especialização em certas funções e alocação de mão de obra, dada a escassez de escravizados na cidade.

Assim, pretendemos a partir da análise do cotidiano de africanos e seus descendentes, explorar os espaços acionados e edificados pelos mesmos: territórios, construções e paisagens. O cotidiano que se politizava e que fazia "desmoronar os pilares da instituição do trabalho forçado". Para além da superação dos "impedimentos" (JACINO, 2018, pp. 116-118) para a história dessas pessoas, que por diversos meios foram impedidas de realizarem-se, vistas, no máximo como o Outro, buscamos contribuir para os estudos que privilegiam em suas análises as organizações, condições de trabalho, educação e aprendizagem, etc. dos trabalhadores escravizados, que vão muito além das dicotomias da transição para o trabalho assalariado - e que geralmente trata o período anterior como uma "pré-história" da história dos mundos do trabalho no Brasil - demonstrando a centralidade desses trabalhadores e trabalhadoras para as experiências de classe (BADARÓ, 2008; BATALHA, 1999; LIMA, 2005; MACCORD, 2012). Por fim, contribuir para o conhecimento das vidas, trajetórias, escolhas das pessoas que foram, ao longo do tempo, esquecidas - propositalmente ou não -, das

Revista da ABPN • v. 12, n. Ed. Especial - Caderno Temático: "Africanos, escravizados, libertos biografias, imagens e experiências atlânticas” • agosto de 2020, 
histórias e memórias, como fundamentais para a construção das cidades, províncias e também do país.

\section{OS CONSTRUTORES DA CIDADE: AFRICANOS, CRIOULOS E OS OFÍCIOS DE CONSTRUÇÃO}

Como afirmou Karasch em seu clássico sobre a escravidão urbana no Rio de Janeiro, os escravos trabalhavam em todas as ocupações possíveis na Corte. Além da aversão ao trabalho manual dentre as elites, inclusive dentre os próprios artesãos, era muito lucrativo alugar cativos especializados. Por ser um bem bastante bem distribuído na Corte, a propriedade de escravos qualificados compunha pequenos cartéis, mas podia superar os ganhos com bens imobiliários (FRANK, 2012, p. 69). Na primeira metade do século XIX, a entrada maciça de africanos para os engenhos de açúcar e café, nos dão os rosto desses cativos, vindos sobretudo da costa central e oriental da África. 2

Além do terceiro setor, o que mais empregava cativos, os ofícios de construção e transformação também empregavam muitos, sobretudo os primeiros. Carpinteiros, marceneiros, canteiros e também ferreiros, eram empregados por estaleiros privados e públicos, obras na própria cidade, como em casas particulares, Igrejas etc. Trabalhando em oficinas ou não, esses oficiais erigiram, literalmente, a cidade oitocentista que avançava em direção a Cidade Nova. Também confundiam a lógica escravista. As fugas, que atendiam aos interesses dos cativos, alteravam as relações escravistas por dentro, possibilitando muitas vezes a saída da condição de escravo, ao "fingir-se" de liberto, e a reunião de pecúlio. Essa antecipação da experiência proletária era praticada por quem? De onde vinham tais cativos? Quais as proporções entre africanos e crioulos dentre os ofícios? Havia diferenças?

Somente a partir da década de 1810 é que podemos ter uma visão mais completa dessas fugas através dos periódicos. Antes disso, dada as proibições tanto para o

\footnotetext{
2 No que se refere às tecnologias importadas durante os séculos de escravismo, Henrique Cunha Jr. chama a atenção para os saberes em torno da produção de navios, culinária, saúde e inclusive, a metalurgia (CUNHA Jr., 2010). Africanos dessas regiões são identificados, grosso modo, ao tronco linguístico bantu. A metalurgia desde, pelo menos, o século X, estava ligada ao comércio e às cidades, em regiões centrais, onde hoje localiza-se a República centro-africana, Angola etc. (VANSINA, 2010, pp. 629-630) Também os povos da parte oriental da África, em que as técnicas metalúrgicas foram inseridas, segundo as tradições, pelo bantus, "seis séculos antes da nossa era". (OCHIENG, pp. 983-984, 2010).
}

Revista da ABPN • v. 12, n. Ed. Especial - Caderno Temático: "Africanos, escravizados, libertos biografias, imagens e experiências atlânticas” • agosto de 2020, p. $140-171$ 
estabelecimento da imprensa, quanto ao de fábricas, torna-se mais difícil o acesso a tais informações. Assim, a liberação da imprensa, de fábricas, e a própria formação do Estado na então colônia tornam a cidade do Rio de Janeiro um espaço em que diversas experiências passam a ser noticiadas, taxadas, ou melhor, documentadas. Interessante notar que as próprias oficinas passam a ser objeto de controle do poder público, através do Código de Posturas, que buscava sanear a cidade e, as fábricas e suas fumaças, tornavam o meio urbano insalubre. Multas para os que não cumpriam as Posturas acerca de onde poderiam localizar-se as oficinas e em relação a sua estruturação (como ter ou não chaminés), geravam constantes embates entre os donos da oficinas e o poder público representado pela Câmara, interessada na arrecadação, dada a condição deficitária do Estado Imperial que formava-se. Tratava-se da própria formação de um espaço fiscal, no qual a oneração ficava a cargo da população urbana, sobretudo, conservando-se assim os interesses agrícola exportadores e escravistas. (RAMOS, 2019, p. 603; COSTA, 2000, p. 62)

Desta forma, o forte movimento migratório que experimenta a cidade desde o início do XIX, estava também umbilicalmente ligado ao forte tráfico de africanos, dado que a mão de obra escrava ainda era, sobretudo na primeira metade do século, muito utilizada dentro da cidade, em atividades diversas. Importante notar como, nesse período, a segunda escravidão também se comportou na cidade, de forma a atender de mão de obra as pequenas oficinas e fábricas, de africanos entrados ilegalmente. A presença de alguns grupos ligados a esse tráfico, explica-se pela importância que tinham os grandes plantéis, sobretudo do café, mas também de outras culturas como a cana, que se apresentavam na praça do Rio de Janeiro. Muitas vezes, portanto, africanos eram revendidos como escravos na cidade através da intermediação de ciganos, crioulos e africanos que obtiveram ao longo do tempo ligações com grupos de traficantes (SOARES, 2011, pp. 60-62; GOMES \& SOARES, 2001, p. 14). Como veremos na próxima seção, esta prática pode estar ligada a diversos fatores, e muitas vezes, contavam com a aprovação dos próprios donos de oficinas.

Se levarmos em consideração aqueles ofícios ligados a produção de máquinas e instrumentos, e a construção, tanto naval, quanto civil, e que, de alguma maneira, tinham uma oficina como espaço de trabalho, poderemos ter um quadro mais amplo de

Revista da ABPN • v. 12, n. Ed. Especial - Caderno Temático: "Africanos, escravizados, libertos biografias, imagens e experiências atlânticas” • agosto de 2020, 
espaços de trabalho em que esses oficiais estavam inseridos e das possíveis diferenças que tinham entre si, no que consiste a idade, origem, identidades, condições de salubridade e possíveis doenças e mazelas, e também, ao acesso que esses trabalhadores tinham ao letramento.

As "nações" que compunham a mão de obra dessas construções acompanhavam, de certa maneira, a própria demografia atlântica do Rio de Janeiro. Entre as décadas de 1810 e 1850, houve grandes alterações dentre os cativos ligados ao trabalho de construção e transformação em pequenas oficinas da cidade. Mas durante todo o período os nacionais, classificados geralmente como crioulos e pardos, foram a maioria dentre os oficiais mecânicos ligados a construção, com pequenas alterações dentre os mesmos, como veremos mais à frente. Consideramos os ofícios ligados a transformação e construção como os que trabalhavam em metais, isto é, de ferreiros, serralheiros, fundidores, latoeiros e caldeireiros; em madeira, como carpinteiros e marceneiros; e em pedra, como canteiros, que esculpiam as pedras retiradas por cavouqueiros, que trabalhavam nas pedreiras da cidade. Tais ofícios não eram os únicos ligados a construção, mas os ofícios que compõem nosso estudo executavam-se, em muitos casos, dentro de oficinas, aproximando-se da experiência dos metalúrgicos.

Outra consideração a ser feita é em relação a subdivisões dentro dos próprios ofícios. Podia-se ser carpinteiro de obra branca, ou de ribeira, isto é, aquele que trabalha com construções de habitações e aqueles que executam trabalhos em madeira para obras navais, respectivamente. Não somente no tipo de carpintaria, mas nos instrumentos, como carpinteiros de machado e de enchó. Também falquejadores, serradores etc compunham as oficinas e obras de carpintaria. Ferreiros podiam ser malhadores, abaixadores, tocadores de foles, e em cada caso a função na produção alterava-se. Como veremos, os tocadores dos foles dentre os ferreiros podiam ser cativos com pouca ou nenhuma visão, podendo ser fruto do próprio trabalho e da sua exposição ao calor sem proteção.

Neste sentido, como vemos na tabela 1, a maior parte dos cativos que trabalhavam na construção e transformação entre 1810-1859, deviam ser carpinteiros. Fato já apontado por Karasch (KARASCH, 2000, p. 277), a forte presença de carpinteiros devia-se, provavelmente a grande demanda dos estaleiros e trapiches que circundavam a

Revista da ABPN • v. 12, n. Ed. Especial - Caderno Temático: "Africanos, escravizados, libertos biografias, imagens e experiências atlânticas” • agosto de 2020, 
baía da Guanabara, mas, também, a um fator tecnológico: a baixa utilização até meados do século XIX de materiais de ferro nas vigas e estruturas das casas; a produção de máquinas para engenhos, e a produção de móveis domésticos - este, mais ligado aos marceneiros.

Tabela 1 - Amostragem de oficiais nos anúncios de jornal, por especialidade e ano $1811-1859$

\begin{tabular}{|c|c|c|c|c|c|c|}
\hline & 1810 & 1820 & 1830 & 1840 & 1850 & Total \\
\hline \multicolumn{7}{|l|}{ Em metal } \\
\hline $\begin{array}{c}\text { Ferreios e } \\
\text { serralheiros }\end{array}$ & 3 & 65 & 92 & 86 & 90 & 336 \\
\hline Fundidores & - & 2 & 2 & 8 & 9 & 21 \\
\hline $\begin{array}{l}\text { Funileiros e } \\
\text { Latoeiros }\end{array}$ & - & 17 & 14 & 22 & 11 & 64 \\
\hline Caldeireiros & - & 5 & 10 & 18 & 10 & 43 \\
\hline Total & 3 & 89 & 118 & 134 & 120 & 464 \\
\hline \multicolumn{7}{|l|}{ Em madeira } \\
\hline Carpinteiros & 15 & 301 & 492 & 662 & 425 & 1895 \\
\hline Marceneiros & 2 & 41 & 100 & 95 & 125 & 363 \\
\hline Total & 17 & 342 & 592 & 757 & 550 & 2258 \\
\hline \multicolumn{7}{|l|}{ Em pedra } \\
\hline Canteiros & - & 30 & 55 & 57 & 47 & 189 \\
\hline Cavouqueiros & - & 4 & 20 & 58 & - & 82 \\
\hline Total & - & 34 & 75 & 115 & 47 & 271 \\
\hline Total & 20 & 465 & 785 & 1006 & 717 & 2993 \\
\hline
\end{tabular}

Fontes: Gazeta do Rio de Janeiro, Correio Mercantil, Diário do Rio de Janeiro e Jornal do Commercio -1810-1859

Podemos afirmar que entre os anos de 1810 e 1849 , as principais diferenças no que se refere aqueles que lidavam com madeira, metal e pedra na cidade encontrava-se nas idades e nas origens. Quanto às idades, ressalta-se um fato já conhecido da historiografia, isto é, a faixa etária desses cativos. Dentre os 770 anúncios que constavam as idades, como vamos na Tabela 2, para o período mencionado, $86,1 \%$ (663) estavam entre os 10 e 29 anos. Concomitante é o envelhecimento desses oficiais entre as décadas de 1810 e 1850 . Se na década de 1810 não surge nenhum anúncio de

Revista da ABPN • v. 12, n. Ed. Especial - Caderno Temático: "Africanos, escravizados, libertos biografias, imagens e experiências atlânticas” • agosto de 2020, 
venda e aluguel de cativos com mais de 40 anos, na década de 1820 já surgem 7 anúncios, na de 1830, 10 e na de 1850,16, ao mesmo tempo que os que tinham entre 20 e 29 anos superam os de entre 10-19 somente na década de 1840. O trabalho e aprendizado de jovens africanos - até a década de 1830 -, passa aos poucos para os mais experientes e crioulos vindos crescentemente das províncias do interior, já habituados aos códigos daquela sociedade escravista, passíveis de serem manipulados no sentido de conquista de maior autonomia, como veremos.

Tabela 2 - Amostragem com idades de oficiais africanos e brasileiros por década -

1811-1859

\begin{tabular}{|c|c|c|c|c|c|c|c|c|c|c|c|c|c|c|c|c|c|}
\hline Décadas & \multicolumn{4}{|c|}{ 1811-1820 } & \multicolumn{4}{|c|}{ 1821-1830 } & \multicolumn{4}{|c|}{ 1831-1840 } & \multicolumn{4}{|c|}{ 1841-1850 } & \multirow[t]{2}{*}{ Total } \\
\hline Idades & $\begin{array}{l}10- \\
19\end{array}$ & $\begin{array}{c}20- \\
29\end{array}$ & $\begin{array}{l}30- \\
39\end{array}$ & $\begin{array}{l}\text { Mais } \\
\text { de } 40\end{array}$ & $\begin{array}{l}10- \\
19\end{array}$ & $\begin{array}{l}20- \\
29\end{array}$ & $\begin{array}{l}\text { 30- } \\
39\end{array}$ & $\begin{array}{l}\text { Mais } \\
\text { de } 40\end{array}$ & $\begin{array}{c}10- \\
19\end{array}$ & $\begin{array}{c}20- \\
29\end{array}$ & $\begin{array}{l}\text { 30- } \\
39\end{array}$ & $\begin{array}{l}\text { Mais } \\
\text { de } 40\end{array}$ & $\begin{array}{l}10- \\
19\end{array}$ & $\begin{array}{l}20- \\
29\end{array}$ & $\begin{array}{l}\text { 30- } \\
39\end{array}$ & $\begin{array}{l}\text { Mais } \\
\text { de } 40\end{array}$ & \\
\hline Em madeira & & & & & & & & & & & & & & & & & \\
\hline Brasileiros & - & 4 & - & - & 18 & 16 & 5 & 4 & 39 & 41 & 4 & 6 & 42 & 61 & 13 & 3 & 256 \\
\hline Africanos & - & - & - & - & 24 & 17 & 1 & 2 & 38 & 32 & 10 & 3 & 23 & 35 & 15 & 7 & 207 \\
\hline Indeterminados & - & - & - & - & 11 & 7 & 1 & 1 & 41 & 31 & 4 & 0 & 40 & 26 & 7 & 0 & 169 \\
\hline Em metal & & & & & & & & & & & & & & & & & \\
\hline Brasileiros & - & 1 & - & - & - & 9 & 1 & - & 2 & 6 & 2 & - & 1 & 6 & 1 & 1 & 30 \\
\hline Africanos & - & - & - & - & 5 & 3 & - & - & 4 & 8 & 3 & 1 & 3 & 7 & - & 3 & 37 \\
\hline Indeterminados & - & - & - & - & 1 & 5 & 1 & - & 6 & 7 & 1 & - & 4 & 4 & - & - & 29 \\
\hline Em pedra & & & & & & & & & & & & & & & & & \\
\hline Brasileiros & - & - & - & - & - & - & - & - & - & - & - & - & - & - & - & - & 0 \\
\hline Africanos & - & - & - & - & 2 & 3 & 1 & - & 2 & 6 & 1 & - & 1 & 5 & 3 & 2 & 26 \\
\hline Indeterminados & - & - & - & - & - & - & - & - & 4 & 4 & - & - & 3 & 5 & - & - & 16 \\
\hline Total & 0 & 5 & 0 & 0 & 61 & 60 & 10 & 7 & 136 & 135 & 25 & 10 & 117 & 149 & 39 & 16 & 770 \\
\hline
\end{tabular}

Fontes: Gazeta do Rio de Janeiro, Correio Mercantil, Diário do Rio de Janeiro e Jornal do Commercio -1810-1859

Um outro ponto interessante a se ressaltar é a quase ausência do "boçal" dentre 2993 anúncios analisados nessa pesquisa, para o intervalo entre 1810-1859. Dessa amostragem, apenas dois carpinteiros africanos foram assim caracterizados. Por isso consideramos que esses oficiais, se africanos, tivessem algum acesso a língua e costumes daquela sociedade, que os permitia circular pela cidade e manipular

Revista da ABPN • v. 12, n. Ed. Especial - Caderno Temático: "Africanos, escravizados, libertos biografias, imagens e experiências atlânticas” • agosto de 2020, 
identidades. Isso também se torna passível de análise quando notamos as diferenças que tais oficiais tinham em relação ao acesso ao letramento mínimo, como ler e escrever. Daquele universo de 2993 anúncios dentre oficiais mecânicos em madeira, metal e pedra, apenas $1 \%$ dos casos foi possível anotar o possível acesso que os mesmos tinham a algum nível de leitura. Esse era um tema delicado, pois, se fugitivo, a informação de que sabia ler e escrever era importante, pois era mais um elemento que favorecia a manipulação de identidade para fazer-se de forro. Desta maneira, temos que a maior parte desses oficiais eram designados como crioulos e pardos, e trabalhavam em ofícios de madeira, sobretudo a marcenaria.

Esses números, mesmo que acanhados em relação ao total de anúncios, nos deixam antever certos aspectos dos ofícios que, possivelmente, propiciavam um acesso mínimo a leitura. Como vemos na Tabela 3, dentre os 26 casos que trabalhavam em madeira, 11 eram marceneiros e 15 eram carpinteiros. Mesmo sendo maioria, os carpinteiros não deviam ser aqueles que mais teriam acesso a leitura e escrita. Pois, proporcionalmente, esses 15 casos representavam apenas $0,7 \%$ de todos os anúncios para carpinteiros (1895) no período supracitado, enquanto os 11 casos entre marceneiros (363) representavam cerca de $3 \%$ do total.

Sabemos que as oficinas eram uma das formas pelas quais escravos e a população pobre em geral podiam ter um acesso, mesmo que rudimentar, ao letramento. No ofício de marceneiro e carpinteiro, por exemplo, essa requisição deveria ser maior que nos outros por alguns motivos. Em primeiro lugar, pela própria necessidade do ofício, que demandava a habilidade de "risco", ou de desenhar e medir as peças que seriam confeccionadas, previamente. Em muitos anúncios de venda e aluguel, sobretudo de carpinteiros, a habilidade de risco é apresentada como um distintivo daquele oficial. ${ }^{3}$ Essa habilidade, possivelmente, deveria requisitar também o ensino de escrita e leitura nas oficinas, para que os mesmos pudessem executar as tarefas. (KARASCH, 2000, p. 297)

\footnotetext{
3 Dentre outros anúncios, há um que vale um comentário, no sentido da posição que um escravizado com ofício poderia ter naquela sociedade, nas relações de compra e venda e, também, no sentido do ensino de ofício (e de desenho?) dentro da comunidade escrava da cidade. Trata-se da venda de Germano, "mestre carpinteiro", em 1852, na Rua Nova do Livramento, n. 23. Era "bem conhecido" na cidade e trabalhava há 14 anos para o mesmo proprietário, segundo anúncio, e só se vendia "por ele o pedir". Além de ser bem conhecido, e contar com alguns possíveis privilégios, Germano entendia de "risco" e era próprio "para ensinar outros escravos". (Jornal do Comércio, n. 165, p. 4, 16 de junho de 1852).
}

Revista da ABPN • v. 12, n. Ed. Especial - Caderno Temático: "Africanos, escravizados, libertos biografias, imagens e experiências atlânticas” • agosto de 2020, p. $140-171$ 
Em segundo lugar, podemos atentar para o caso das oficinas de marceneiro funcionarem também como lojas de pequenas obras do ofício. Como no caso de Pedro Rosiere, na rua da Quitanda n. 20, que, em 1850, tinha "sempre um bom e lindo sortimento de trastes fabricados na sua oficina, conforme os gostos mais modernos, e que se vendem por preços muito moderados”. Desta oficina fugiu, neste mesmo ano, Polidorio, pardo, aprendiz de marceneiro, de 19 anos. O marceneiro, segundo anúncio tinha "jeitos de capoeira", tinha "trocado o nome acima pelo de Domingos José dos Santos, e havia ido sentar praça". ${ }^{4}$ Polidoro, ou Domingos José, utilizava de certas táticas muito comuns entre cativos naquele momento para conquistar a liberdade, como veremos com mais vagar a frente.

Quanto aos metalúrgicos, também, proporcionalmente, pouco anúncios foram encontrados com aqueles que tinham a habilidade de "ler e escrever". Apenas 3 casos foram encontrados entre os ofícios com metal, e todos designados como crioulos. Quanto aos africanos, 2 anúncios, somente, constam de africanos, um carpinteiro e um canteiro. $\mathrm{O}$ anúncio de fuga deste último revela alguns traços importantes em relação aos africanos naquele contexto. José, de nação Congo havia fugido no dia 15 de março de 1836, sabia ler e escrever e o anunciante pedia atenção dobrada ao fiscal das embarcações, pois julgava-se que ele tivesse "ido para fora da terra". 5

O cuidado com uma fuga definitiva de José deveria ser grande, por ele, na verdade, parecer liberto e comportar-se como tal, usando "cabelo crescido a francesa", sabendo ler e escrever. José também parecia crioulo, o que, na visão senhorial, era mais um motivo de distinção que poderia confundir a sua captura. O outro caso também é interessante. Cosme, Mina, carpinteiro, havia fugido no dia 12 de junho, apenas 7 dias depois da publicação do primeiro anúncio ${ }^{6}$ - um caso atípico, como veremos.

$\mathrm{Na}$ verdade, Cosme devia ter relação de confiança com seu proprietário, pois quando houve a fuga - que não deveria ser um costume -, "tinha licença para se alugar em qualquer obra dentro da cidade, porém serviu-se dela para fugir". Por isso, seu proprietário publicou o anúncio uma semana depois da fuga. Além de saber ler, Cosme utilizava-se muito bem dos códigos presentes naquela sociedade, pois andava "calçado e

Diário do Rio de Janeiro, n. 8506, p. 4, 25 de setembro de 1850.

Diário do Rio de Janeiro, n. 2, p. 4, 5 de abril de 1836.

Jornal do Comércio, n. 155, p. 4, 19 de junho de 1841

Revista da ABPN • v. 12, n. Ed. Especial - Caderno Temático: "Africanos, escravizados, libertos biografias, imagens e experiências atlânticas” • agosto de 2020, p. $140-171$ 
de relógio", dificultado a sua descoberta. Em seção a parte, analisaremos casos como o de Cosme, José e Polidorio, cabendo aqui ressaltar que, os acessos a leitura, como outras habilidades e comportamentos, poderiam facilitar o acesso aquilo que consideravam como autonomia, africanos ou não.

Além da habilidade de ler e escrever, num sentido mais amplo, havia sim uma aquisição e uso dos conhecimentos da cultura formal, na operação "do mercado financeiro e de crédito, além do manuseio da moeda" (SARAIVA \& ALMICO, 2017b, pp. 40-41). O impacto dessa participação, que se mostrava na reunião de poupança, uso de papéis e comércio são alguns aspectos dessa cultura formal praticada pelos cativos, ao longo do XIX. Como dito, analisaremos com mais vagar esse ponto em outra seção deste estudo, mas cabe lembrar, que mesmo que pequeno o número daqueles minimamente alfabetizados, a grau dessa participação pode ser medido também num sentido mais amplo.

Voltando aos africanos, mesmo que minoritários, e tendo uma certa experiência em solo nacional - como vemos a partir dos anúncios, e da ausência de "boçais" -, como podemos definir a distribuição dos africanos entre os ofícios e dentre a própria demografia africana na cidade ao longo do século XIX? Quais as principais "nações" que compunham essa força de trabalho no XIX? Havia diferenças entre os ofícios, ou seguiam uma média, relacionada mais a entrada de africanos a partir do tráfico? Essas e outras questões buscaremos analisar com mais vagar na próxima seção.

Tabela 3 - Amostragem de oficiais cativos que sabiam ler e escrever 1810-1859

\begin{tabular}{ccccc}
\hline & Em madeira & Em metal & Em pedra & Total \\
\hline Africano & 1 & 0 & 1 & 2 \\
$\begin{array}{c}\text { Crioulos e } \\
\text { pardos }\end{array}$ & 25 & 3 & 0 & 28 \\
Total & 26 & 3 & 1 & 30 \\
\hline
\end{tabular}

Fontes: Gazeta do Rio de Janeiro, Correio Mercantil, Diário do Rio de Janeiro e Jornal do Commercio -1810-1859

Revista da ABPN • v. 12, n. Ed. Especial - Caderno Temático: "Africanos, escravizados, libertos biografias, imagens e experiências atlânticas” • agosto de 2020, 
Utilizando-se da mesma divisão por grandes regiões de embarque, proposta por Karasch, evidenciam-se números muito semelhantes daqueles dados atuais em torno da demografia escrava na cidade do Rio de Janeiro para o século XIX, mas com alguns detalhes importantes de serem frisados. Os números de entrada de africanos durante o período entre as décadas de 1800-1840 variam entre 470 mil até 600 mil africanos aportados na cidade do Rio (ELTIS, 2000; FLORENTINO, 1995; KARASCH, 2000).

Com base em estudo clássico de Karasch (2000, p. 45), que analisou tais dados a partir de registros de fontes diversas, para o intervalo de 1830-1852, segue-se a mesma predominância para africanos centro ocidentais, seguidos por africanos orientais e depois ocidentais. Contudo, proporcionalmente, há diferenças. Vejamos, nos dados apresentados por Karasch, no intervalo citado, africanos centro ocidentais, vindos de regiões de Angola e do Congo Norte, representavam quase a totalidade (79,2\%), seguidos por africanos orientais $(17,9 \%)$ e ocidentais (1,5\%). Para os registros de óbitos da Santa Casa da Misericórdia para os anos de 1833, 1838 e 1849, os números são um pouco distintos, africanos centro ocidentais representavam $68,3 \%$, enquanto orientais e ocidentais, respectivamente, $16,8 \%$ e 6,3\%. Nações não identificadas e origens africana desconhecidas somam $8,5 \%$.

Algumas diferenças dos números apresentados por Karasch foram evidenciadas, a partir de revisões recentes, a partir da leitura de outras fontes, como registros de batismos e inventários post-mortem, para o fim do século XVIII e primeira metade do XIX. A partir da análise comparativa de registros paroquiais e inventários post-mortem, para o período de 1801-1830, Gomes registra algumas diferenças, tanto em relação aos dados apresentados anteriormente por Karasch, quanto entre si. Diferenças estas ligadas ao próprio funcionamento do tráfico.

Além da predominância do africano central ocidental, que abordaremos mais à frente, há uma diferença grande entre os registros de batismo (13\%) e dos inventários (4\%) dos africanos orientais. As hipóteses para tal diferença, relacionam-se com o batismo realizado na cidade da grande quantidade de "moçambiques" que seriam, muitas vezes, reexportados para outras regiões de produção agrícola; tal como a redução da representação nos inventários relaciona-se a ausência de novos proprietários, que somente passam a ser representados partir da década de 1840 , já que os inventários

Revista da ABPN • v. 12, n. Ed. Especial - Caderno Temático: "Africanos, escravizados, libertos biografias, imagens e experiências atlânticas” • agosto de 2020, p. $140-171$ 
entre 1801-1830 não registram esses novos proprietários, que surgem com mais força no tráfico desses africanos orientais, sobretudo na década de 1820 (GOMES, 2012, pp. 99100).

Nos registros de fuga, aluguel e venda para os intervalos entre 1810-1859, publicados sobretudo no Jornal do Commercio, confirma-se a hipótese da presença dos novos proprietários de escravos na primeira metade do século e o grande contingente de africanos orientais, sobretudo moçambiques. Mesmo que muitos tenham sido vendidos para outras regiões, muitos permaneciam na cidade, como vemos a partir da Tabela 4, $20 \%$ desses africanos vinham da região oriental do continente africano, designados genericamente como moçambiques, quilimanes, inhambanes e senas.

Tabela 4 - Amostragem com grandes regiões de embarque de africanos oficiais por década (1810-1859)

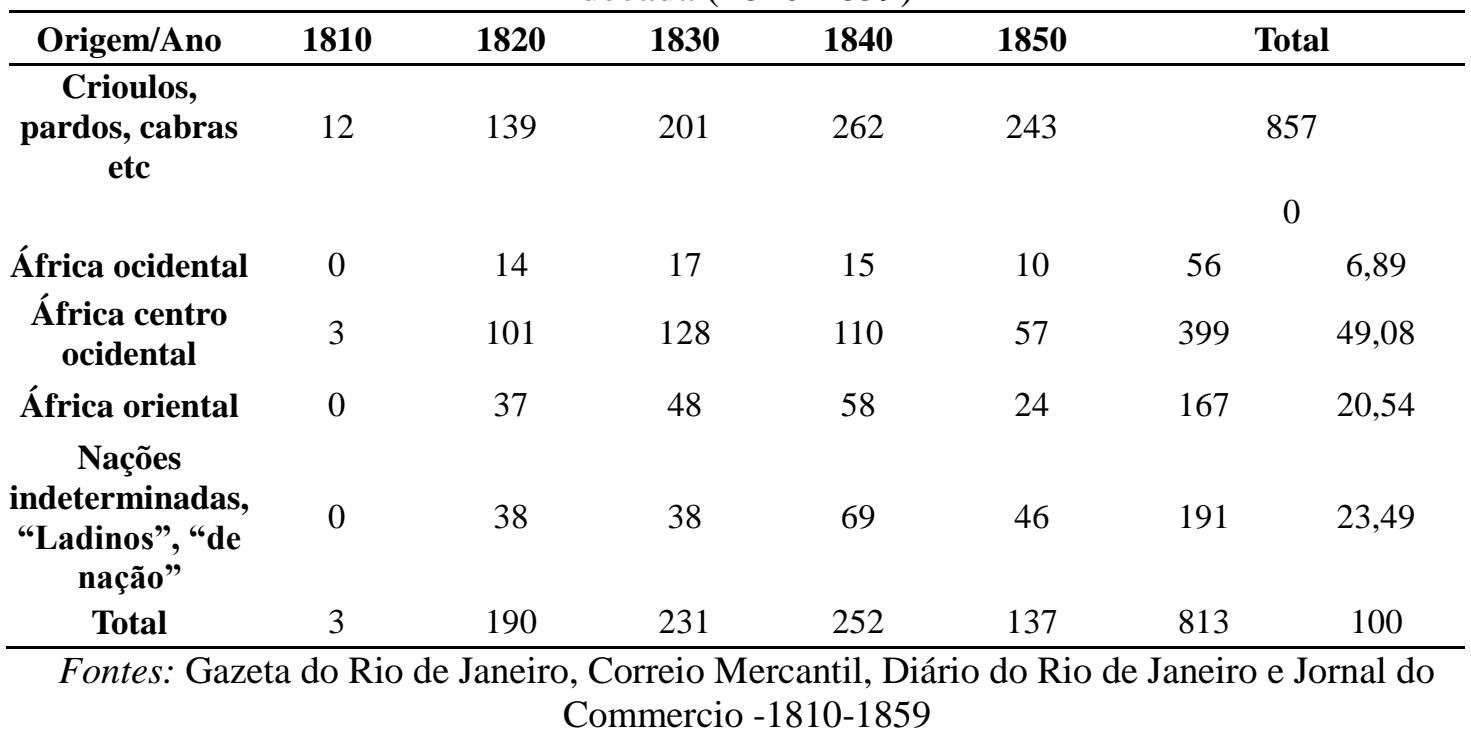

Somente nas décadas de 1820 e 1830, africanos orientais representaram 20,5\% de todos os africanos carpinteiros, ferreiros, canteiros etc, como podemos ver na Tabela 4. Assim, pequenos proprietários urbanos estavam comprando esses africanos e os empregando em pequenas oficinas. Analisaremos com mais vagar as possíveis consequências da predominância $(70,1 \%)$ de africanos orientais e centro ocidentais na comunidade escrava e de fugitivos, livres e libertos. Mas cabe adiantar que nem sempre pela compra tais africanos entravam nos registros dos periódicos, mas muitas vezes pela fuga de regiões do interior da província ou do país.

Revista da ABPN • v. 12, n. Ed. Especial - Caderno Temático: "Africanos, escravizados, libertos biografias, imagens e experiências atlânticas" • agosto de 2020, 
Entre os ferreiros, canteiros e carpinteiros, por exemplo, havia uma maioria de designados como moçambiques, proporcionalmente maior que nos outros ofícios. Dentre os carpinteiros, os especificamente designados como moçambiques representavam 13,9\% dos africanos, ferreiros, $11,7 \%$ e, canteiros, 18,9\%. Esses números podem apontar que, por exemplo, era mais fácil encontrarmos um africano moçambique trabalhando nessas oficinas, que um africano ocidental de qualquer das "nações" apontadas.

Quanto aos centro ocidentais, sua predominância na cidade está presente também no nosso levantamento, representando $49,08 \%$ de todos os africanos com ofício presentes nos anúncios de jornais. Africanos provenientes das regiões do Congo Norte, como os congos, cabindas, monjolos e moanges, representavam 48,6\% dos 399 africanos da costa centro ocidental. Mas, em contrapartida, os provenientes de Angola (sul e norte), representavam 51,4\% dos mesmos, corroborando a hipótese da subrepresentarão dos mesmos nos registros de batismo, estar relacionada com o já batismo dos provenientes de angola, cassanges no Norte, e benguelas no sul de Angola (GOMES, 2012, p. 95).

Aqui devemos nos deter a alguns aspectos importantes antes de prosseguirmos. Entre os ferreiros o número de africanos centro ocidentais, entre os anos de 1810-1870, alcançava $58,8 \%$ do total de africanos, isto é, $10 \%$ a mais que entre carpinteiros, por exemplo, que tinham 48,5\% vindos dessa região e que o computo geral de centro ocidentais entre os oficiais, que era $49 \%$. Dentre os metalúrgicos centro ocidentais, $54,2 \%$ vinham da região do Congo Norte, isto é, Cabinda, Congo, Monjolo, Moange e outros $45,7 \%$ vinham de Angola, sobretudo a região do norte de Angola, e eram designados comumente como angolas, cassanges e rebolos.

Africanos de angola deveriam já ser batizados, conhecer alguma coisa da língua e da cultura e religião católica, dada a presença dos portugueses naquela região. Esse deve ser o caso de Antonio, carpinteiro, nação Angola de 16 anos e havia desaparecido no dia 28 de janeiro de 1831. O anunciante apontava que Antonio, ao querer passar-se de forro poderia enganar alguns mestres de embarcações, pois "parece crioulo".7 Ou José, "oficial de carpinteiro, de nação Rebolo", 20 anos. Fugira no começo de fevereiro de

\footnotetext{
${ }^{7}$ Diário do Rio de Janeiro, n. 8, p. 4, 10 de fevereiro de 1831
}

Revista da ABPN • v. 12, n. Ed. Especial - Caderno Temático: "Africanos, escravizados, libertos biografias, imagens e experiências atlânticas” • agosto de 2020, p. $140-171$ 
1837 e "na fala parece crioulo". 8 Também Silvana, que fora possivelmente "desencaminhada por um preto carpinteiro de nome Primo", era Cassange, "porém parece crioula". 9

Portanto, de maneira geral, esses africanos vindos da região de sul de Angola deveriam ter certo contato com a cultura local e serem inclusive batizados, como dito anteriormente. Luanda ainda no século XVIII tinha escravos e libertos engajados em serviços mecânicos Lanço a hipótese de que esses cativos africanos que trabalhavam como oficiais no núcleo urbano, talvez não tivessem passado por aquela fase de adaptação nas fazendas, sendo comprados nas cidades sob a intermediação de ciganos, através do roubo - e que estavam presentes no tráfico em Luanda desde o século XVIII , como também poderiam ter sido seduzidos e "acoitados". (ALFAGALI, 2017, p. 62; GOMES \& SOARES, 2001, pp. 16-17). Assim pode ter sido o caso de José, fugido da rua do Propósito n. 20, no dia 19 de março de 1846. De nação congo e com "2 dentes da frente limados", o anunciante desconfiava que José estaria sendo "acoitado em alguma loja".10 Ou Manuel de "mais de 50 anos" em 1846, nação cabinda, ferreiro e cozinheiro. Desconfiava-se que estivesse "acoitado em alguma ferraria ou casa onde cozinhe".11 De modo talvez distinto, havia alguns anúncios em que esse acoitamento era explicitamente posto como escolha do cativo. Como no caso do pardo Manoel, alfaiate e carpinteiro, e talvez estivesse na Lagoa, em 1839, em "um sítio do falecido Logy, acoitado por uma preta”.12

Por fim, os africanos ocidentais seguiam entre os oficiais o mesmo padrão da demografia mais geral da cidade. Apenas 56 casos foram encontrados por mim entre os anos de 1810-1859 em todos os ofícios. Mas isolando apenas os que eram designados apenas como minas, estes aparecem como a $6^{a}$ maior nação referida nos anúncios ao longo desses anos. Entretanto, dentre os ferreiros, por exemplo, encontramos apenas 6 minas e 9 africanos ocidentais até a década de 1860, seguido por 2 calabar e 1 nagô. Mesmo sendo minoritários entre a totalidade dos africanos, eles devem ter tido um papel importante de aglutinação na comunidade escrava da cidade do Rio de Janeiro de

\footnotetext{
Diário do Rio de Janeiro, n. 19, p. 4, 27 de fevereiro de 1837

Jornal do Comércio, n. 116, p. 4, 29 de abril de 1857

Diário do Rio de Janeiro, n. 7172, 31 de março de 1846, p.4

Diário do Rio de Janeiro, n.7224, 4 de junho de 1846, p. 4

Diário do Rio de Janeiro n. 162, p. 4, 23 de julho de 1839
}

Revista da ABPN • v. 12, n. Ed. Especial - Caderno Temático: "Africanos, escravizados, libertos biografias, imagens e experiências atlânticas" • agosto de 2020, 
então. Pois quando fugiu o crioulo Joaquim, crioulo, oficial de carpinteiro de 26 anos e que sabia ler, desconfiava-se que estivesse "em casas de pretos Minas, pelas ruas do Aljube, Fogo, Conceição, travessa da Pedreira, e rua do Príncipe”, pois costumava acoutar-se por lá. ${ }^{13}$ Já Theophilo, um mina liberto de 40 anos de idade fora condenado a 4 anos e 6 meses de galés, além de multa por ter "furtado" 14 a Luiza, escrava de João José da Cruz. Talvez, ao tentar fugir ou seduzir a mesma, teve sua tentativa frustrada e acabou preso. Mas ressalta-se que esses africanos, mesmo que minoritários, não pareciam estar isolados da comunidade escrava em geral, mesmo se libertos. Mesmo africanos ocidentais pareciam ter também um certo conhecimento da cultura e costumes locais, dado que o fugitivo Manoel de nação Mina, podia dizer que era forro, "porque é muito ladino". 15

Como veremos na próxima seção, muitos desses africanos e também ladinos, tinham experiências que confundiam aquela cidade escravista. $\mathrm{O}$ capitalismo carbonífero aqui contava com um repertório distinto.

\section{COTIDIANO E OFÍCIOS: AUTONOMIAS, LETRAMENTO E MAZELAS DA ESCRAVIDÃO NA CIDADE}

Sebastião fora fugido, pelo que se dizia, para a então Corte, em meados de 1821. Fugido da Fazenda Itaindiba, em São Paulo, Sebastião ia para a cidade do Rio de Janeiro com uma finalidade: assentar praça no Batalhão do Libertos. Ao saber que fora denunciado, Sebastião desertou, antes que o Comandante o alcançasse. Avisado por companheiros de farda e/ou atento ao que poderia acontecer, Sebastião antecipou-se aos fatos. ${ }^{16}$

Ferreiro, alfaiate, sabendo ler e escrever, Sebastião talvez estivesse voltando para o Rio de Janeiro após uma venda indesejada para outra província. Sabe-se que sua mãe residia nos subúrbios ou freguesias rurais da Corte, "por Mataporcos, Campo Grande", assim, recomendava-se aos pedestres dessas áreas uma maior vigilância. Victoria, liberta, mãe de Sebastião também devia saber que ele andava pela restinga de

13 Jornal do Commercio, n. 115, p. 4, 1857.

14 Diário do Rio de Janeiro n. 186, p. 2, 22 de agosto de 1838.

15 Diário do Rio de Janeiro, n. 10, p. 4, 13 de novembro de 1826.

16 Diário do Rio de Janeiro, n. 10, p. 4, 12 de abril de 1824.

Revista da ABPN • v. 12, n. Ed. Especial - Caderno Temático: "Africanos, escravizados, libertos biografias, imagens e experiências atlânticas" • agosto de 2020, p. $140-171$ 
Copacabana. Tendo um ofício, o crioulo ferreiro de 28 anos, em 1824, buscava certa autonomia, refazendo laços familiares, rompidos pela escravidão e, portando-se como liberto.

Tendo "sido visto em toda a cidade", também Juvencio buscava refazer laços ${ }^{17}$. Serralheiro e ferreiro, já havia trabalhado no Arsenal de Guerra e em "diversas lojas". Por isso Juvencio parecia ser conhecido pelos mestres de obras da cidade, pois sabia-se que tinha pai e mãe forros que residiam no beco dos Ferreiros, local em que poderiam ficar alertas aqueles que estavam interessados pelas recompensas da sua captura. Como também no Rio Comprido, onde tinha um irmão que fora vendido há pouco tempo, e por lá desconfiava-se que andasse.

Esse hábito gerava em certos momentos, determinadas reações das classes senhoriais, possíveis de serem lidas nas fontes. Tais reações, no sentido de afastar-se o cativo, crioulo ou africano, da própria cidade, entendido como um teatro dos seus vícios (CHALHOUB, 1990, p. 198). Por isso, muitos anúncios constavam a venda, exclusivamente, para fora da Corte. Fujões e seus hábitos rompiam os esquemas instituídos do controle senhorial na cidade, e a venda para fora funcionava como uma punição ao cativo, e uma tentativa de controle da própria cidade.

Estar na cidade significava também maiores chances de conseguir-se a alforria. $\mathrm{O}$ hábito de comprar a própria liberdade, juntando o pecúlio, fora formalizado apenas na lei de 28 de setembro de 1871, mas mesmo assim parece ter sido recorrente através da própria fuga, e da manipulação de identidades. Causas como as aproveitadas por Juvencio e Sebastião, tendo suas trajetórias marcadas pela passagem na Armada e no Exército, eram as mais comuns para esta finalidade (NASCIMENTO, 2000; KRAAY, 2012).

A grande quantidade de libertos e livres, além de cativos de outros proprietários, tornava quase impossível o reconhecimento de um fugitivo por um dono de oficina que não concordasse em correr o risco de admitir um possível fujão. Por isso a necessária precisão nos caracteres fisionômicos dos cativos nos anúncios, sobretudo nos de fuga (COUCEIRO, 2003, pp. 64-65). Toda a recriação de identidades envolvidas nesses casos nos apontam para os caminhos pelos quais esses "escravos oficiais" construíram a

17 Diário do Rio de Janeiro, n. 9057, p. 4, 5 de agosto de 1852.

Revista da ABPN • v. 12, n. Ed. Especial - Caderno Temático: "Africanos, escravizados, libertos biografias, imagens e experiências atlânticas" • agosto de 2020, p. $140-171$ 
liberdade nos diversos espaços produtivos, como nas forjas, oficinas, canteiros de obras. Mesmo que a maior parte do tempo distantes das ruas, essas pessoas teciam redes de solidariedades, manipulavam identidades e, de certa forma, forjavam autonomias (BRITTO, 2011, p. 180).

Ao "inculcar-se" forro, o africano ou brasileiro escravizado acionava uma série de significados ligados a estigmas de ser escravo, expressos nas roupas, nos modos de se portar e falar. Como vimos anteriormente, poucos oficiais eram caracterizados como boçais, sinalizando que os mesmos, se africanos, já tinam passado por aquela fase de adaptação, ocorrida muitas vezes nas fazendas e engenhos, onde o controle senhorial tornava-se mais direto, ou mesmo no outro lado do Atlântico. A proximidade com senhores libertos e livres nas oficinas também deve ter fomentado essa facilidade em manipular as identidades. Sabe-se, por exemplo, que colonos utilizavam, em determinados momentos, as mesmas estratégias dos cativos por maior autonomia (ALENCASTRO, 1988, pp. 44-45), mesmo que essa não tenha a sido a regra. Da casa Rohe Irmãos, fábrica de seges e carruagens, fugira um alemão chamado Augusto Luschky, ferreiro. Protestava-se no anúncio que se atentassem os proprietários a não dar serviço e couto a Augusto. ${ }^{18} \mathrm{Ou}$ no caso de Antonio Cordeiro, também colono e carpinteiro, que desapareceu depois de ir "com um Sr. engenheiro encarregado do concerto de pontes."19

A busca por autonomia desses oficiais, que conviviam com setores livres e negociavam suas possíveis autonomias com esses setores, e a comunidade escrava, sobretudo em relação a família reflete-se na participação desses oficiais, no que pode chamar-se de um mercado de trabalho livre, ainda não completamente regulamentado (SANTOS, 2013, pp. 25-27; 152) e num mercado de bens financeiros propriamente ditos. As fontes nos deixam apenas prescrutar o quanto o cativo realmente comportavase como forro, e o quanto agiam guiados por escolhas que se referiam ao mundo dos libertos. Mas os números relacionados ao movimento de conquista de liberdade por compra da mesma - como comentado em relação a lei de 28 de setembro de 1871, entre os anos de 1820-1880, sobretudo no meio urbano, demonstram essa crescente

18 Jornal do comércio, n. 130, p. 3, 13 de maio de 1859.

19 Diário do Rio de Janeiro n. 277, p. 4, 6 de dezembro de 1838

Revista da ABPN • v. 12, n. Ed. Especial - Caderno Temático: "Africanos, escravizados, libertos biografias, imagens e experiências atlânticas” • agosto de 2020, 
autonomia, e participação nesses mercados de bens e de trabalho (SARAIVA \& ALMICO, 2017b, p. 42).

Caso emblemático no sentido de participação no mercado de bens financeiros, foi o noticiado em fevereiro de 1845 pelo Jornal do Commercio. Nele, constava que Antonio Maria, fugiu de S. Cristovão no dia 14 de janeiro daquele ano - um mês antes da publicação do anúncio. ${ }^{20}$ Dizia-se que o mesmo havia iludido a mãe "para que lhe desse os $220 \$ 000$ rs que a mesma havia tirado um vigésimo". Em troca do possível roubo, o carpinteiro dizia, segundo anúncio, "que tinha um senhor" que compraria um outro cativo, para dar a ele a seu senhor. Não sabemos se Antonio Maria pensou em traçar um caminho mais rápido para a alforria, roubando a quantia de sua mãe, ou se o carpinteiro fora enganado por um sedutor de escravos e/ou negociante interessado no seu valor. Mas o reconhecimento da possibilidade de isso ter acontecido como roubo, nos mostra como havia entre senhores e escravos a compreensão dessas falhas, e as relações que podiam entreter com a "sociedade envolvente".

Outro caso nesse mesmo sentido fora o do pardo Querino, fugido em fevereiro de 1827. ${ }^{21}$ Como não havia voltado, em março daquele ano, seu proprietário anuncia sua fuga. Além de fugir, Querino, pardo, carpinteiro, levou sua caixa de ferramentas possível de ser utilizada ou vendida pelo mesmo. Em fevereiro de 1829, após indas e vindas, surge novo anúncio de fuga de Querino. ${ }^{22}$ Neste, o anunciante faz questão de expor que o mesmo estava sendo protegido por um taverneiro que prometia o fazer passar para fora. $\mathrm{O}$ anunciante dava um prazo para o devolver-se de 8 dias, pois tinha testemunhas do fato. Não sabemos onde morava o dito taverneiro que acoutava Querino, mas caso fosse realmente verdadeiro, e lesse o anúncio, saberia que se referia a ele, e sua fuga para fora, poderia ser desfeita, se não já tivesse acontecido.

Estar na cidade não significava necessariamente mais liberdade. O também crioulo Domingos provavelmente buscava trilhar o caminho do interior, fora da cidade e suas oficinas. Ferreiro, com idade de 30 anos, dizia-se nascido no próprio Rio de Janeiro, onde sua mãe também residia. ${ }^{23}$ Domingos havia fugido de Resende, da vila do Barreiro, e seu proprietário, Antonio Pereira Leite, devia desconfiar que Domingos

20 Jornal do Comércio, n. 41, p. 4, 11 de fevereiro de 1845

Diário do Rio de Janeiro, n. 8, p. 4, 9 de março de 1827

Diário do Rio de Janeiro, n. 18, p. 4, 21 de julho de 1829

Correio Mercantil, n. 330, 22 de novembro de 1860, p. 3.

Revista da ABPN • v. 12, n. Ed. Especial - Caderno Temático: "Africanos, escravizados, libertos biografias, imagens e experiências atlânticas” • agosto de 2020, p. $140-171$ 
estivesse na cidade ou tivesse passado por ela, trabalhando em suas imediações, pois sabia que intitulava-se forro, "ajustando-se para trabalhar em roças para não dar-se a conhecer pelo seu ofício, pois é perfeito oficial de ferreiro". Habituado a fugir, e com cicatrizes que o fariam ser reconhecido como escravo, Leite só publicou o anúncio em 22 de novembro daquele ano, um mês depois da fuga, considerando talvez que Domingos estivesse por perto e fosse achado, ou voltaria. Já Domingos sabia que podia ser reconhecido e denunciado, trabalhando nas oficinas da cidade, pois era perfeito oficial de ferreiro. Não sabemos com quem o ferreiro ajustava a saída da cidade, mas buscava apresentar-se e comportar-se como liberto - com o conhecimento ou não de quem o auxiliava -, indo trabalhar ao ganho no interior, ou nas diversas chácaras em torno do núcleo urbano da corte.

Não só os crioulos, já habituados com a língua e com possíveis laços familiares, que podiam os auxiliarem nessa busca por maior autonomia. Em 1831 também fugiu Manoel, de nação Moçambique, de uma oficina na rua da Prainha, na freguesia de Santa Rita. ${ }^{24}$ Com 16 anos, Manoel havia fugido sem chapéu, apenas com duas camisas e duas calças. Quatro meses depois de sua fuga e três meses depois do primeiro anúncio, um novo relato aparece nos jornais, referindo-se a Manoel, que tinha como sinal mais marcante uma cicatriz na perna direita, fruto de uma ferida. ${ }^{25}$ Neste segundo anúncio, e segunda fuga, o anunciante sabia que possivelmente Manoel havia fugido junto com "um preto Mina Ferreiro", que trabalhava, naquela época da fuga, com o moçambique em um fazenda em Três Barras, possivelmente alugado. No anúncio não se explicita se o tal ferreiro que o acompanhava era liberto, ou escravo, como Manoel, mas a ligação dos africanos ocidental e oriental, pode ter gerado a desconfiança de uma fuga conjunta dos mesmos. O também africano João deveria pensar como Manoel, Domingos e Querino. Com cerca de 30 anos em 1831, desconfiava-se que estivesse trabalhando "nos subúrbios da cidade, e nas roças". ${ }^{26}$ João era de nação Congo, carpinteiro e também ferreiro, e havia fugido da rua do Catete n. 101, em 29 de agosto daquele ano. Através de diversas maneiras, mesmo africanos buscavam fugir, e muitas vezes para fora da cidade, onde teriam mais oportunidades de esconderem-se, mas também,

\footnotetext{
Diário do Rio de Janeiro, n. 4, 7 de abril de 1831, p. 4.

Diário do Rio de Janeiro, n. 9, 11 de julho de 1831, p. 4.

Diário do Rio de Janeiro, n. 10, 13 de janeiro de 1832, p. 4.
}

Revista da ABPN • v. 12, n. Ed. Especial - Caderno Temático: "Africanos, escravizados, libertos biografias, imagens e experiências atlânticas" • agosto de 2020, p. $140-171$ 
paradoxalmente, maiores chances de serem descobertos, e presos, ou vendidos para locais em que não poderiam exercer o que consideravam liberdade.

Sendo assim, o risco de permanecer na cidade, relacionava-se a uma possível prisão. Muitos senhores escolhiam deixar os cativos fugitivos reincidentes, algum tempo na Correção ou, até mesmo, vendê-lo após ser preso. O Calabouço e a Casa de Correção eram os principais destinos para aqueles descobertos pela malha fina da polícia da Corte, fiscais de quarteirão e aqueles interessados nas recompensas, indicando aquele novo poder que surgia na relação privada entre senhor e escravo, sobretudo no meio urbano da Corte (FERREIRA, 2005). O africano Chrispim, de nação Cabinda, talvez tenha tido esse destino. Em 17 de novembro de 1840 o Diário do Rio de Janeiro noticiou a fuga do ferreiro, ocorrida dois dias antes do anúncio. ${ }^{27}$ Não sabemos o rumo que Chrispim tomou em sua fuga, mas fora descoberto rápido e já constava um anúncio de venda para ele, na Casa de Correção, onde deveria estar cumprindo prisão com trabalho, com outros africanos, estes "livres".

A Casa de Correção era, em suma, o destino para os "escravos viciosos". ${ }^{28}$ Vicioso podia significar, naquele período, uma gama de comportamentos tidos como indesejáveis, ou como afirmavam alguns anunciantes de venda, aluguel e fuga de cativos, ao longo do século XIX, "fujões, bêbados ou ladrões"29. Os fujões, pois desorganizavam as regras estabelecidas em relação a mão de obra escrava; bêbados eram aqueles que não compartilhavam, muitas vezes, na visão senhorial, do sentido de disciplina que buscava-se impor ao trabalho e ao trabalhador naquele momento. E ladrões, pois atacavam a propriedade, âmago das justificativas pró-escravistas naquele período. Ao fugirem, beberem e frequentarem "súcias", além de roubarem, muitas vezes suas próprias ferramentas de trabalho, essas pessoas podiam sofrer punições como ir para a Correção, ${ }^{30} \mathrm{ou}$ serem vendidas para fora.

\footnotetext{
27 Diário do Rio de Janeiro, n. 259, 17 de novembro de 1840, p. 4.

28 Jornal do Commercio, n. 68, 27 junho de 1840, p. 3.

29 Diário do Rio de Janeiro, n. 4, 1824, p. 2, ou Diário do Rio de Janeiro, n. 16, p. 2, 20 de novembro de 1826 e Jornal do Commercio, n. 42, p. 4, 11 de fevereiro de 1847.

30 Assim, germinava-se "um dos fundamentos teóricos da estratégia de atuação" das polícias nas primeiras décadas do século XX, numa identificação entre cor, pobreza e vício, que buscava, através da suspeição generalizada, manter o controle, de maneira legal, sobre os trabalhadores após 1888 (CHALHOUB, 1996, pp. 23-24; Idem, 1990, pp. 219-220; SANTOS, 2011). Nesse mesmo sentido, as tentativas de controle sobre a movimentação dos cativos confirmam-se inclusive nas leis emancipacionistas. Como se sabe, havia até 1885 uma tentativa de controlar a circulação dos recém-
}

Revista da ABPN • v. 12, n. Ed. Especial - Caderno Temático: "Africanos, escravizados, libertos biografias, imagens e experiências atlânticas” • agosto de 2020, p. $140-171$ 
Juntamente com os já citados arsenais de marinha e de guerra, a Correção era um espaço em que esses africanos e nacionais, muitas vezes aprendiam de maneira nem sempre, voluntária um ofício, ou o exerciam. As condições de trabalho nesses estabelecimentos não deviam diferir-se muito das pequenas oficinas do núcleo urbano. Com diferença fundamental que no caso das oficinas da Casa de Correção, buscava-se abertamente moralizar o detento, através do trabalho, antecipando muitas questões presentes em períodos posteriores.

Além de oficinas internas, a Casa de Correção podia ceder seus detidos e africanos livres para outros departamentos do Estado Imperial, como às Bibliotecas, obras públicas, limpeza de ruas, controle de incêndios etc. Além desses casos, o detido poderia sair se fosse ocupar-se em alguma função da Correção em obras externas e oficinas, nesses casos as possibilidades de fugam aumentavam, como no ocorrido com Francisco José, caracterizado como mendigo pelo Chefe de Polícia no dia 2 de abril de 1849.

Fugido da ferraria da "oficina do Pedroso", Francisco José enganara o sentinela, lançou mão do método que muitos dos escravizados de então faziam e fugiu. ${ }^{31}$ Contando ou não com a vista grossa da sentinela, Francisco José fugiu daquela oficina, em plena luz do dia, de maneira quase banal. Sabe-se que Pedroso tinha oficina própria (ARAÚJO, 2009, p. 171) e contava com vários detentos da Correção como mão de obra, na feitura de portas para as celas. Naquele mesmo ano de 1849, um ofício assinado por Miranda Falcão afirma em tom de reclamação que

(...) além prestação mensal de duzentos mil réis, dá-se lhe também como aqui achei estabelecido, um feitor vencendo dezenove mil e duzentos réis mensalmente, três africanos ferreiros, um dos quais [é] bom oficial, e outro já trabalha menos mal, três serventes [ilegível] para conduzir carvão. Ora, ainda quando os três africanos mereçam um jornal superior ao de mil e quinhentos réis [por] dia todos três, e quinhentos réis os outros serventes, há um excedente de contribuição da parte da Casa de Correção [ilegível] mil réis para mais por mês, além de ser preciso ter uma sentinela na ferraria e o ocorrerem outros incovenientes, os quais contudo hão de desaparecer, quando se tiver efetuado a mudança de albergaria, conforme $\mathrm{V}$. Ex ${ }^{\mathrm{a}}$ me autorizou a fazer. Em presença do que levo expedido, V. Ex ${ }^{a}$ se dignará ordenar o que for de justiça (AN - Série

libertos pela chamada Lei dos Sexagenários, para assim, atrelá-los aos espaços de trabalho. (MANOEL, 2020, p. 29)

31 AN - Série Justiça. IJ7-11 Casa de Correção da Corte, 05/1849

Revista da ABPN • v. 12, n. Ed. Especial - Caderno Temático: "Africanos, escravizados, libertos biografias, imagens e experiências atlânticas” • agosto de 2020, p. $140-171$ 
Justiça IJ7 - 11. Casa de Correção. Ofícios com Anexo. (1849 - 1850), 26/04/1849)

Um feitor, três africanos ferreiros, sendo um oficial, além de mais três serventes, com exceção da sentinela, assim talvez se dividisse a maioria das oficinas de ferreiro da cidade naquele momento. Tanto quanto os vencimentos dos operários empregados, nos quais eram três vezes maiores que a dos serventes. Nesse caso, africanos eram os ferreiros.

Esse caso é importante por deixar revelar certos traços do próprio espaço de produção e da divisão do trabalho nessas pequenas oficinas. Outra oficina, que funcionava na rua dos Latoeiros n. 84, ${ }^{32}$ está de funileiro, também contava com uma quantidade semelhante de operários e uma diferenciação interna no valor dos escravizados. Dos 12 escravos arrolados em seu inventário, três eram de serviço de casa, dois chacareiros e sete eram funileiros. Se considerarmos que um desses funileiros podia ser o feitor, também são sete o número de oficiais, como no caso da oficina de Pedroso.

Dos sete funileiros, dois estavam com a idade ilegível, ambos de nação Cabinda, e os únicos africanos no serviço de funilaria do plantel. Um deles, Francisco, era tinha o valor menor que a metade do mais caro dentre eles, Joaquim, crioulo, de 20 anos. Alguns fatores devem ser considerados para as diferenças nos valores dos jornais, venda e aluguel dos cativos. Idade, mazelas e doenças podem ser vistas como parte dessa desvalorização.

Quadro 1 - Funileiros cativos na oficina de Polidora Ludovina Gonçalves por nome, origem, idade, ocupação e preço

\begin{tabular}{cccc}
\hline Nome & Idade & Ocupação & Preço \\
\hline 1. Jerônimo, crioulo & 23 anos & Funileiro & $1: 600 \$ 000$ \\
2. Joaquim, idem & 20 anos & Funileiro & $1: 700 \$ 000$ \\
3. Bento, idem & 15 anos & Funileiro & $1: 500 \$ 000$ \\
4. Domingos, Cabinda & Idade ilegível & Funileiro & $1: 100 \$ 000$ \\
5. Dolcino [sic.], pardo & 22 anos & Funileiro & $1: 800 \$ 000$ \\
6. Laurindo, pardo & 25 anos & Funileiro & $1: 900 \$ 000$ \\
7. Francisco, Cabinda & Idade ilegível & Funileiro & $600 \$ 000$ \\
\hline
\end{tabular}

Fonte: AN - Juízo de órfãos e ausentes. Inventário post-mortem de Polidora Ludovina Gonçalves, 1857.

32 Almanack Administrativo, Mercantil e Industrial da Corte e da Província do Rio de Janeiro, 1847.

Revista da ABPN • v. 12, n. Ed. Especial - Caderno Temático: "Africanos, escravizados, libertos biografias, imagens e experiências atlânticas” • agosto de 2020, 
Em outra documentação, agora de arrematação de escravos ocorrida em 1852, surgem outros dados que podem nos ajudar a pensar nessa questão. De um leilão de dez cativos que deveria ocorrer na casa de Carlos Honório Figueiredo, rua dos Inválidos n. 14. Sendo todos africanos, três constavam como "amassador de pão e ferreiro". A lista os dividia por ocupação, idade, nação, mazelas e preços. Dentre os três ferreiros, como vemos na tabela, Pedro, o de menor preço, tinha como mazela ser rendido da parte esquerda. Ser africano e ter 40 anos talvez não fosse o fator explicativo do preço menor dado a Pedro em relação a João e Joaquim, mas uma mazela que o impedia de cumprir certas funções na produção.

Quadro 2 - Oficiais ferreiros por nome, origem, idade, ocupação, mazelas e preço

\begin{tabular}{|c|c|c|c|c|c|}
\hline Nome & Nação & Idade & $\begin{array}{c}\text { Ocupa } \\
\text { ção }\end{array}$ & $\begin{array}{c}\text { Mazela } \\
\text { s }\end{array}$ & Preço \\
\hline $\begin{array}{c}\text { Joaqui } \\
\mathrm{m}\end{array}$ & $\begin{array}{c}\text { Cabind } \\
\text { a }\end{array}$ & 34 anos & $\begin{array}{l}\text { Ferreiro e } \\
\text { Amassador } \\
\text { de pão }\end{array}$ & - & $\begin{array}{c}700 \$ \\
\text { réis }\end{array}$ \\
\hline João & Cabinda & 30 anos & $\begin{array}{l}\text { Ferreiro e } \\
\text { Amassador } \\
\text { de pão }\end{array}$ & - & $\begin{array}{c}700 \$ \\
\text { réis }\end{array}$ \\
\hline Pedro & $\begin{array}{l}\text { Moçam } \\
\text { bique }\end{array}$ & 40 anos & $\begin{array}{l}\text { Ferreiro e } \\
\text { amassador } \\
\text { de pão }\end{array}$ & $\begin{array}{c}\text { Rendid } \\
\text { o da } \\
\text { parte } \\
\text { esquerd } \\
\text { a }\end{array}$ & $\begin{array}{c}450 \$ \\
\text { réis }\end{array}$ \\
\hline
\end{tabular}

Fonte: Correio Mercantil, n. 190, 9 de julho de 1852, p. 3

Casos como esses eram comuns e fazem parte daquele repertório no qual senhores escolhiam vender seus escravizados. As fugas, fatos constantes ao longo desse período, talvez não tivessem uma relação direta com as condições de saúde dos cativos, ou por aquelas mazelas causadas por castigos, dado que, mesmo com após a cessação do tráfico em 1850 e a melhora nas condições de saúde dos cativos, que vinha ocorrendo desde a década de 1830, pelo o aumento de preço que esses tinham no mercado, as fugas permaneceram ocorrendo, por aqueles que tinham alguma moléstia causada pelos rigores do trabalho e castigos (AMANTINO, 2007, p. 13870. Doenças causadas por traumas, de fundo reumático e psíquicas continuavam presentes entre os fugitivos.

Revista da ABPN • v. 12, n. Ed. Especial - Caderno Temático: "Africanos, escravizados, libertos biografias, imagens e experiências atlânticas” • agosto de 2020, p. $140-171$ 
A partir de então, surge uma economia racional dos proprietários, dada a escassez de mão de obra. Essa economia, imposta pela nova posição ocupada pelo país na economia mundo industrial oitocentista (VIANA \& GOMES, 2019, p. 89)- e outros locais do atlântico ${ }^{33}$-, demandava uma maior lucratividade, sobretudo das fazendas de café, em que cativos eram postos a trabalhar nas plantações para, assim, aumentar a lucratividade. Esse movimento pode ter acontecido também em cidades como o Rio de Janeiro, onde encontramos casos em que escravizados, com doenças - como no caso de Pedro Moçambique -, tinham seu valor de mercado reduzido, ao mesmo tempo que permaneciam em seus ofícios, talvez, em outras funções que não aquelas em que trabalharam durante a vida. Era uma forma de se reaproveitar essa mão de obra, buscando-se lucratividade a partir dos mesmos, ou através do aluguel e venda.

Alguns casos são emblemáticos nesse sentido de permanência das condições duras de trabalho e de venda e aluguel de escravos com algum tipo de moléstia, como dizia-se na época. Suas marcas eram descritas como maneiras de os distinguir dos outros tantos libertos, livres e cativos que deviam dividir com eles as oficinas. Como no caso de Bento, de 35 a 40 anos de idade, carpinteiro e de nação. Bento tinha marcas que o fariam ser rapidamente reconhecido por pedestres ou policiais na Corte pois tinha "um dedo torto na mão direita, e uma cicatriz em um pé, resultado de um corte de machado, e falta-lhe uma orelha”. Sabendo do grande risco em ser descoberto, Bento andava "sempre com um lenço atado na cabeça". 34

Ou no caso de José, Ganguela de 24 anos. José fugiu em setembro de 1832 junto com Luiz, de nação Cabinda. O primeiro, para ser reconhecido mais facilmente, fora anunciado com "alguns sinais de queimadura por ser Ferreiro". ${ }^{35}$ Ou Manuel de nação Cabinda que fugira em 1846. Manuel tinha, além de “dois dedos menores da mão direita

33 Refiro-me ao conceito de segunda escravidão, cunhado por Dale Tomich, em que houve, sinteticamente, uma reorganização da produção e do mercado mundial, tornando algumas regiões do Brasil, Cuba e Sul dos Estados Unidos, entre os séculos XVIII e XIX e o fim das escravidões nas Américas, como produtoras principais de açúcar, café e algodão para o mercado mundial. As interpretações de Tomich sobre a escravidão moderna contribuem para perspectivas históricas em torno dos significados trabalho compulsório no oitocentos, e para as diversas condicionantes políticas (internacionais inclusive), culturais, etc para sua permanência ao longo do século. (TOMCIH, 2011; SALLES \& MARQUESE, 2016)

34 Jornal do Commercio, n. 102, p. 3, 13 de abril de 1847

35 Diário do Rio de Janeiro, n. 24, 23 de outubro de 1833, p. 4

Revista da ABPN • v. 12, n. Ed. Especial - Caderno Temático: "Africanos, escravizados, libertos biografias, imagens e experiências atlânticas” • agosto de 2020, p. $140-171$ 
aleijados", tinha na perna esquerda, acima do tornozelo "uma cicatriz de queimadura". ${ }^{36}$ Como apontou Amantino, a "situação patológica mais apresentada pelos escravos (...) refere-se ao tipo infectocontagioso", no caso, a varíola. Africanos também eram os mais acometidos pela doença na cidade do Rio de Janeiro. Seguido das doenças infectocontagiosas, as mazelas causadas por traumas eram a segunda mais comum entre cativos, como queimaduras, fraturas, feridas e surras com instrumentos de castigo (AMANTINO, 2007, pp. 1385-86).

Além das marcas recorrentes de cicatrizes e feridas de castigos, havia marcas de nação, e de doenças, como a "bexiga", ou varíola, dentre outras moléstias, talvez, causadas pelo próprio serviço que faziam diariamente, como no caso das queimaduras. Assim, ferreiros, como vimos, eram divididos em pelo menos três funções dentro de uma oficina: o que trabalhava diretamente na forja ${ }^{37}$ o malhador e o tocador de foles. Os primeiros, possivelmente, tinham uma maior prática e deviam servir como feitores e/ou contramestres nas oficinas. ${ }^{38}$ A partir da década de 1840 , começam a surgir anúncios em que aquela economia racional parece ter se manifestado de maneira mais clara. Um aspecto importante surge no caso dos ferreiros, em que uma mazela aparece com mais frequência, ou exclusivamente entre esses, isto é, a cegueira. O aparecimento desses anúncios a partir da década de 1840 talvez se explique pela escassez de ferreiros na cidade e pela alocação dos que existiam com algum trauma físico, em determinados serviços, como tocar foles. Encontramos 13 casos como esse, entre 1810-1870, somente entre ferreiros.

Não temos informações acerca da origem desses cativos, sendo designados apenas como "pretos". Também as idades não ficam explícitas, apenas em um caso, em que alugava-se um "preto cego" de 20 anos, na rua da Alfândega n. 194, próprio para tocar rodas e foles de ferreiro. ${ }^{39}$ Também outro caso interessante foi o da existência de uma mulher, "quase cega, mas sadia, serve para tocar foles de ferreiro, ou coisa

\footnotetext{
Diário do Rio de Janeiro, n.7224, 4 de junho de 1846, p. 4

Correio Mercantil, n. 290, 22 de novembro de 1850, p. 4

Diário do Rio de Janeiro, n. 20, 24 de dezembro de 1834; p. 3, Diário do Rio de Janeiro, n. 174, 7 de agosto de 1841, p. 3; Diário do Rio de Janeiro, n. 286, 21 de dezembro de 1843, p. 4

39 Diário do Rio de Janeiro, n. 272, 6 de dezembro de 1842, p. 3
}

Revista da ABPN • v. 12, n. Ed. Especial - Caderno Temático: "Africanos, escravizados, libertos biografias, imagens e experiências atlânticas” • agosto de 2020, p. $140-171$ 
semelhante", ${ }^{40}$ na rua de S. Pedro n. 168. O primeiro e o segundo caso podem refletir duas situações distintas que ocorriam na cidade com ferreiros.

O tocador de foles na cultura dos africanos centrais, mais especificamente os dos provenientes de Reino do Kongo, era peça principal no processo de fundição e reparo de ferro, pois haviam desenvolvido "técnicas sofisticadas de produção de ferro, controlando por meio de um delicado equilíbrio a quantidade de ar insuflada no forno pelos foles" (ALFAGALI, 2017, p. 219). Ou seja, mais que um trabalho repetitivo e extenuante, o tocar foles para esses africanos centro ocidentais, eram saberes guardados por essas populações no controle do ferro e do fogo, e da atribuição mágico-religiosa dada a essas práticas (Idem, p. 228).

Tabela 5 - Amostragem de ferreiros tocadores de foles com falta ou pouca visão (18101869)

\begin{tabular}{cccccccc}
\hline & $\mathbf{1 8 1 0}$ & $\mathbf{1 8 2 0}$ & $\mathbf{1 8 3 0}$ & $\mathbf{1 8 4 0}$ & $\mathbf{1 8 5 0}$ & $\mathbf{1 8 6 0}$ & Total \\
\hline Aluguel & 0 & 0 & 1 & 4 & 1 & 1 & 7 \\
Venda & 0 & 0 & 0 & 3 & 3 & & 6 \\
Total & 0 & 0 & 1 & 7 & 4 & 1 & 13 \\
\hline
\end{tabular}

Fontes: Gazeta do Rio de Janeiro, Correio Mercantil, Diário do Rio de Janeiro e Jornal do Commercio - $1810-1869$

Não obstante a presença de cativos cegos para tocar foles, havia outros oficias que poderiam exercer tal tarefa, tendo também alguma sequela de doenças ou falta de membros, como foi o caso da venda de um "preto aleijado de uma perna, para puxar foles sentado", na praia do Peixe n. 15. Ou um preto velho, em 1850, custando $80 \$$ réis, saudável, "tendo só os pés e pernas um pouco inchadas, mas não por erisipelas, carcunda por hábito, serve para tocar foles de ferreiro ou roda de torneiro."

Desta forma, deveria conviver uma política de menor custo por parte dos senhores em relação aos cativos com alguma mazela que o limitasse, e a presença de tocadores de foles que já tinham certa experiência nessa prática por já serem ferreiros e que, continuando nas oficinas pelos saberes e experiências acumuladas, eram alugados ou vendidos por um preço menor, mesmo cegos, por terem um know-how. Não podemos, a partir das fontes em que nos debruçamos, realmente afirmar que havia em todos os casos uma atribuição mágico-religiosa para a feitura dos metais, sobretudo por

40 Diário do Rio de Janeiro, n. 6732, 2 de outubro de 1844, p. 4

Revista da ABPN • v. 12, n. Ed. Especial - Caderno Temático: "Africanos, escravizados, libertos biografias, imagens e experiências atlânticas” • agosto de 2020, 
africanos, mas não devia ser algo intangível, dado o papel que o ferreiro tinha nas sociedades escravistas nas Américas.

\section{CONSIDERAÇÕES FINAIS}

O aprendizado de ofícios - cada vez mais alheio às corporações desde 1824 - ia sendo feito no interior das oficinas, nas quais escravos podiam aprender com outros cativos ou libertos, perpetuando tradições, ritos e ritmos de trabalho fortemente impregnados nas populações africanas, sobretudo centro ocidentais, que eram a maioria dos cativos no Rio de Janeiro naquele momento. Significados diversos poderiam ter esses espaços de trabalho, sobretudo na primeira metade do século XIX, em que a população africana ainda era considerável.

Os territórios das oficinas, que não abandonavam o núcleo urbano, mesmo com as medidas regulamentadoras da Câmara e do saber médico, podem ter fomentado a recriação de tradições envolvidas no método de trabalho dos ferreiros, carpinteiros, canteiros, africanos e nacionais? Ao mesmo tempo em que e escravidão era defendida como mão de obra, muitas vezes por justificativas liberais de defesa da propriedade, os cativos através da "experiência do cativeiro", forjavam suas próprias ideologias de progresso, civilização e liberdade. (NASCIMENTO, 2000)' Ao passo que para libertos, compartilhar as forjas e oficinas com escravizados poderia ser um risco de serem atrelados ao passado e origens escravas, para os cativos, significava uma oportunidade de livrarem-se do peso do cativeiro (BRITTO, 2012, p. 23). Libertos e cativos misturavam-se, no cotidiano das ruas, oficinas, obras, lojas, em práticas e comportamentos, nem sempre distinguíveis a olho nu, criando novas espacialidades, que seriam logo atacadas pelas elites, através de intervenções urbanas profundas ao longo do século XX, marcadas pela segregação socioespacial.

Assim, buscamos contribuir para os estudos sobre o trabalhador negro livre no pósabolição, com as experiências de trabalhadores - que eram seus pais, avós, tios -, que ritualizavam e ressignificavam seus ofícios por outras mediações, além daquelas esperadas pelos patrões sobre o que poderia ser o bom trabalhador.

Revista da ABPN • v. 12, n. Ed. Especial - Caderno Temático: "Africanos, escravizados, libertos biografias, imagens e experiências atlânticas" • agosto de 2020, 


\section{REFERÊNCIAS BIBLIOGRÁFICAS}

ALENCASTRO, Luiz Felipe de. Proletários e Escravos: imigrantes portugueses e cativos africanos no Rio de Janeiro, 1850-1872. Novos Estudos, no 21 - julho de 1988.

AMANTINO, Márcia. As condições físicas e de saúde dos escravos fugitivos anunciados no Jornal do Commercio (RJ) em 1850. História, Ciências, Saúde, Manguinhos -Rio de Janeiro, v. 14, n. 4, p. 1377-1399, out-dez. 2007.

ARAÚJO, Carlos Eduardo Moreira de. Cárceres imperiais: a Casa de Correção do Rio de Janeiro - seus detentos e o sistema prisional do Império (1830-1861). Tese (Doutorado) Instituto de Filosofia e Ciências Humanas, Universidade Estadual de Campinas, Campinas, 2009.

Arquivo Nacional. Juízo de órfãos e ausentes. Inventário post-mortem de Polidora Ludovina Gonçalves, 1857.

Arquivo Nacional. Série Justiça. IJ7-11 Casa de Correção da Corte, 05/1849.

Arquivo Nacional. Série Justiça IJ7 - 11. Casa de Correção. Ofícios com Anexo. (1849 1850), 26/04/1849.

BATALHA, Claudio H. M. Sociedades de trabalhadores no Rio de Janeiro do século XIX: algumas reflexões em torno da formação da classe operária, Cadernos AEL. Campinas, v. 6, n. $10-11,1999$.

BRITTO, Maura Silveira Gonçalves de. Com luz de ferreiro: práticas do ofício nas Minas de ferro escravistas, século XIX. Dissertação (Mestrado em História) - UFOP, Mariana, MG, 2011.

. O ferreiro e a forja no universo da escravidão: experiências de homens de cor nas Minas de ferro escravistas. Anais do XVIII Encontro Regional (ANPUH-MG), Mariana - MG, 2012.

CERTEAU, Michel: A invenção do cotidiano: 1. Artes de fazer. Petrópolis: Vozes, 1996.

CHALHOUB, Sidney. Cidade febril: Cortiços e epidemia na Corte imperial. São Paulo: Companhia das Letras, 1996.

. Visões da liberdade: uma história das últimas décadas da escravidão na Corte. São Paulo: Cia das Letras, 1990.

COSTA, Wilma Peres. Finanças e construção do Estado: fontes para o estudo da história tributária do Brasil no século XIX. America Latina en la Historía Económica, Ciudad de Mexico, v. 15, n. $13 / 14$, p. $62,2000$.

Correio Mercantil, $1830-1868$

COUCEIRO, Luiz Alberto. Bumerangue encapsulado: um estudo sobre a construção social da subjetividade numa cidade escravista. Rio de Janeiro, c. 1860-1888. Rio de Janeiro: 7Letras, 2003.

CUNHA Jr. Henrique. Tecnologia Africana na Formação Brasileira. Rio de Janeiro: CEAP/MEC. 2010.

Diário do Rio de Janeiro, 1821 - 1879

ELTIS, David. The rise of african slavery in the Americas. Cambridge: Cambridge University Press. 2000.

Revista da ABPN • v. 12, n. Ed. Especial - Caderno Temático: "Africanos, escravizados, libertos biografias, imagens e experiências atlânticas" • agosto de 2020, 
FLORENTINO, Manolo Garcia. Em costas negras: uma história do tráfico atlântico de escravos entre a África e o Rio de Janeiro (séculos XVIII e XIX). Rio de Janeiro: Arquivo Nacional. 1995.

FERREIRA, Roberto Guedes. "Autonomia escrava e (des)governo senhorial na cidade do Rio de Janeiro da primeira metade do século XIX", in FLORENTINO, Manolo (org.). Tráfico, cativeiro e liberdade (Rio de Janeiro, séculos XVII-XIX). Rio de Janeiro: Civilização Brasileira, 2005.

FRANK, Zephyr. Entre ricos e pobres: o mundo de Antonio José Dutra no Rio de Janeiro oitocentista. Minas Gerais: Annablume, 2012.

Gazeta do Rio de Janeiro, 1809-1822

GOMES, Flávio. A demografia atlântica dos africanos no Rio de Janeiro, séculos XVII, XVIII e XIX: algumas configurações a partir dos registros eclesiásticos. Hist. cienc. saúde Manguinhos [online]. 2012, vol.19, suppl.1.

GOMES, F. Dos S. e SOARES, C. E. L. 2001. "Em busca de um 'risonho futuro': seduções, identidades e comunidades em fuga no Rio de Janeiro escravista (século XIX)". Locus - Revista de História 7 (13): 9-29.

HELLER, Agnes. O Cotidiano e a História. São Paulo: Editora Paz e Terra, 2008.

JACINO, Ramatis. Tebas e o legado africano na produção da riqueza e na urbanização. In.: FERREIRA, Abilio (org.); CERQUEIRA, C. G.; YOUNG, Emma; JACINO, Ramatis; CHIARETTI, Maurílio. Tebas: um negro arquiteto na São Paulo escravocrata (abordagens). São Paulo: IDEA, 2018. Jornal do Commercio, 1827 - 1879.

KARASCH , Mary. A vida dos escravos no Rio de Janeiro: 1808-1850.Trad. Pedro Maia Soares, São Paulo, Companhia das Letras, 2000.

KRAAY, Hendrik. Os companheiros de Dom Obá: Os zuavos baianos e outras companhias negras na guerra do Paraguai. Afro-Ásia. 2012;46:121-161

LEMOS, Rennan de Souza. Uma arqueologia da paisagem urbana de Amarna: Ritual e religiosidade no Egito Antigo (c. 1350-1330 a. C). Monografia apresentada ao curso de Graduação em História. Niterói: UFF, 2011.

LIMA, Henrique Espada. "Sob o domínio da precariedade: escravidão e os significados da liberdade de trabalho no século XIX”. Topoi, v. 6, n. 11, jul./dez. 2005, p. 289-326.

MANOEL, Júlio Cesar Costa. A Lei dos Sexagenários como estratégia para manutenção da precaridade socioespacial no Brasil. Revista da ABPN, v. 12, n. Ed. Especial -Caderno Temático: "Geografias Negras" • abril de 2020, p. 12-31.

MATTOS, Marcelo Badaró. Escravizados e livres: experiências comuns na formação da classe trabalhadora carioca. Rio de Janeiro: Bom Texto, 2008.

NASCIMENTO, Álvaro Pereira do. Do cativeiro ao mar: escravos na Marinha de Guerra. Estud. afro asiát., Rio de Janeiro, n. 38, p. 85-112, Dec. 2000.

Revista da ABPN • v. 12, n. Ed. Especial - Caderno Temático: "Africanos, escravizados, libertos biografias, imagens e experiências atlânticas" • agosto de 2020, p. $140-171$ 
OCHIENG, W.R.. O interior da África do Leste: os povos do Quênia e da Tânzania (15001800). In.: OGOT, Bethwell Allan. História Geral da África, V: África do século XVI ao XVIII. Brasília: UNESCO, 2010.

SOARES, Luis Carlos. O "povo de cam" na capital do Brasil: a escravidão urbana no Rio de Janeiro do século XIX. Rio de Janeiro: Faperj/7 Letras, 2011.

SALLES, Ricardo \& MARQUES, Rafael. Escravidão e capitalismo histórico no século XIX: Cuba, Brasil e Estados Unidos. Rio de Janeiro: Civilização Brasileira, 2016.

SANTOS, Milton. A Natureza do Espaço: Técnica e Tempo, Razão e Emoção. São Paulo: Editora da Universidade de São Paulo, 2006.

SARAIVA, L. F \& ALMICO, R. C. da Silva. Saber ler, contar e poupar: reflexões entre economia popular e cultura letrada no Rio de Janeiro, 1831/1864. In: VENANCIO, Giselle Martins; FERRERA, Maria Verónica Secreto de; RIBEIRO, Gladys Sabina Ribeiro (Org.). Cartografias da cidade (in)visível: cultura escrita, educação e leitura de populares no Rio de Janeiro Imperial. Rio de Janeiro: Mauad, 2017b.

VIANA, Iamara da Silva; GOMES, Flávio dos Santos. Do "mercado imperfeito": sobre corpos, africanos e médicos no Rio de Janeiro oitocentista. Revista Maracanan, [S.1.], n. 21, p. 71-96, jul. 2019.

SANTOS, Lucimar Felisberto dos. Africanos e crioulos libertos no Rio de Janeiro: legislação, percepções políticas e mobilidade social de ex-escravos (1870-1890). Revista Saeculum Revista de História. v. 25; João Pessoa, jul/dez. 2011. pp. 77-96.

. A negação da herança social: africanos e crioulos no mundo da liberdade, do capital e do trabalho. Rio de Janeiro - 1872-1906. Universidade Federal da Bahia (Tese de doutoramento); Salvador, 2013.

RAMOS, Eduardo Silva. Organização Alfandegária e espaços fiscais no Império brasileiro (1808-1836). Almanack, Guarulhos, n. 21, p. 565-608, 2019.

TOMICH, Dale. Pelo prisma da escravidão. Trabalho, Capital e Economia Mundial. São Paulo: Edusp, 2011.

TUAN, Yi-Fu (1975). Place: an experiential perspective, Geographical Review, 65, 2, pp. 151-165.

VANSINA, Jan. A África equatorial e Angola: as migrações e o surgimento dos primeiros Estados. In.: NIANE, Djibril Tamsir (ed.). História geral da África, IV: África do século XII ao XVI. Brasília: UNESCO, 2010.

Recebido 03/07/2020

Aprovado em 22/07/2020

Revista da ABPN • v. 12, n. Ed. Especial - Caderno Temático: "Africanos, escravizados, libertos biografias, imagens e experiências atlânticas” • agosto de 2020, p. $140-171$ 